Quim. Nova, Vol. 35, No. 5, 988-992, 2012

\title{
VOLTAMMETRIC DETERMINATION OF SIBUTRAMINE IN BEVERAGES AND IN PHARMACEUTICAL FORMULATIONS
}

\author{
Juliana M. Carvalho, Andrea R. da Silva, Alessandra L. M. C. da Cunha e Ricardo Q. Aucélio* \\ Pontifícia Universidade Católica do Rio de Janeiro, Rua Marquês de São Vicente, 225, 22453-900 Rio de Janeiro - RJ, Brasil
}

André Luis M. Alberti e Katia C. Leandro

Departamento de Química, Instituto Nacional de Controle de Qualidade em Saúde, Fundação Oswaldo Cruz, Av. Brasil, 4365,

21040-360 Rio de Janeiro - RJ, Brasil

Recebido em 6/10/11; aceito em 30/11/11; publicado na web em 23/1/12

\begin{abstract}
A simple and sensitive method has been proposed for the determination of sibutramine- $\mathrm{HCl}$ in energy drinks, green tea and pharmaceutical formulations using differential pulse voltammetry performed on a hanging mercury drop electrode. In the chosen experimental condition (Mcllvaine $\mathrm{pH} 4.0$ buffer, $50 \mathrm{mV}$ pulse amplitude and $40 \mathrm{mV} \mathrm{s}^{-1}$ scan velocity), sibutramine- $\mathrm{HCl}$ presented a reversible behavior and a peak maximum at $-80 \mathrm{mV}$. Detection limit was $0.4 \mathrm{mg} \mathrm{L}^{-1}$ and the working linear range extended up to $33.3 \mathrm{mg} \mathrm{L}^{-1}(\mathrm{r}=0.99)$. Analysis of real and fortified samples enabled recoveries between 91 and $102 \%$. The electroanalytical method was compared with a HPLC method which indicated it accuracy.
\end{abstract}

Keywords: sibutramine; differential pulse voltammetry; pharmaceutical formulations.

\section{INTRODUCTION}

Obesity is a complex condition with serious social and psychological dimensions that affects virtually all age and socioeconomic groups in both developed and developing countries. ${ }^{1}$ The health impact of overweighting is so marked that obesity has now been classified as a major global public-health problem. ${ }^{2}$ The World Health Organization projects 700 million adults will be clinically obese by 2015 and at an increased risk of developing other chronic diseases such as diabetes mellitus type II, coronary heart disease, hypertension, and various types of cancer. ${ }^{3} \mathrm{~A}$ drug therapy might be considered if obesity persists despite diet, physical exercise and modification if life-style.

Drugs used to aid in weight loss can be divided into two categories based of their mechanisms of action: appetite suppressants and lipase inhibitors. ${ }^{4}$ Appetite suppressors are no longer indicated due to its high potential to drug dependency. 5-hydroxytryptamine reuptake inhibitors such as fenfluramine and dexfenfluramine were approved for obesity, but they were immediately withdrawn from the market because they were associated with pulmonary hypertension and increasing of the incidence of heart valve disease. Sibutramine, $N$-(1-(1-(4-chlorophenyl)-cyclobutyl)-3-methylbutyl)$N, N$-dimethylamine, is a serotonin and noradrenalin reuptake inhibitor $^{5,6}$ currently used as an anti-obesity drug in the hydrochloride form. Sibutramine increases concentrations of HDL-cholesterol and lower triglycerides-levels, but can raise blood pressure and pulse rate. ${ }^{7,8}$ Because of these collateral effects, the illicit addition of sibutramine in energy drinks has been reported. The LD50 for sibutramine is $64 \mathrm{mg} \mathrm{kg}^{-1}$ (oral uptake in mouse). ${ }^{9}$ In 2010, sibutramine was removed from the European market, based on new data from the Sibutramine Cardiovascular Outcomes Trial (SCOUT), which demonstrated an increased risk of non-fatal cardiovascular events, such as stroke or heart attack, ${ }^{8,10}$ therefore, the Agency's Committee for Medicinal Products for human use has concluded that any benefit brought by the use of sibutramine do not compensate the risks imposed to the patients. ${ }^{11,12}$ In this same year, the U.S. Food

\footnotetext{
*e-mail: aucelior@puc-rio.br
}

and Drug Administration recommended against prescription and use sibutramine based medicines and requested the withdraw of products containing this drug from the United States market. ${ }^{13}$ Based on the SCOUT results, the Brazilian National Agency of Sanitary Vigilance published the RDC n.25, allowing the prescription of sibutramine for the treatment obesity for no longer than 60 days and limited in $15 \mathrm{mg}$ the maximum daily dose of the drug. ${ }^{12}$

The public has also been looking for alternative sliming treatments that include phytotherapy such as the so called green teas. Upon promises of fast and effective weight loss offered by the suppliers, the presence of non-declared synthetic substances (adulterants) in the phytotherapic products has been increased. However, such practice violates the laws of most of the countries. Due to its anti-depressant and appetite inhibition properties, sibutramine may be fraudulently included in commercial energy drinks and in diet-oriented green tea commercial formulations, therefore, this is a serious public health problem. In fact the Brazilian National Agency of Sanitary Vigilance (ANVISA) has reported cases of adulteration of athlete food and complements beverages. ${ }^{14}$

The United State Pharmacopoeia does not indicate an official method for the quantification of sibutramine hydrochloride monohydrate, but a few methods have been described in the literature using high performance liquid chromatography with UV photometric ${ }^{15}$ and mass spectrometric detection, ${ }^{16,17}$ capillary electrophoresis with UV detetion, ${ }^{7,18}$ UV absorption spectrophotometry ${ }^{19}$ and infrared spectroscopy. ${ }^{20}$

Voltammetric methods enable the sensitive and selective measurement of organic compounds based on their specific electrochemical behavior at the working electrode surface. ${ }^{21,22}$ Electrochemical methods are advantageous if the selectivity achieved eliminates the need for separation procedures, which simplifies procedures, enables short analysis times and lower cost of analysis by using a relatively cheaper instrument and less consumables. ${ }^{23}$

In the present work, a simple and sensitive analytical method based on the differential pulse voltammetry was developed for the determination of sibutramine hydrochloride (sibutramine-HCl). The method was applied in the analysis of pharmaceutical formulations and beverages such as green tea and energy drinks samples. 


\section{EXPERIMENTAL}

\section{Instrumentation}

Voltammetric measurements (diferential pulse voltammetry) and mechanism studies (using square wave voltammetry) were carried out with a model 757 VA Metrohm attached to a multi-electrode system formed by a mercury working electrode (HMDE) with $0,3187 \mathrm{~mm}^{2}$ surface area, an auxiliary electrode (platinum wire) and a reference electrode $\mathrm{Ag} / \mathrm{AgCl}\left(\mathrm{KCl} 3 \mathrm{~mol} \mathrm{~L}^{-1}\right)$. The digital analytical balance (AG 285 model, $0.01 \mathrm{mg}$ sensitivity) of Mettler Toledo was used for weighing standards and samples. Chromatographic measurements were performed on a Waters chromatograph with UV-vis absorption photometric detector (wavelenght set a $230 \mathrm{~nm}$ ). The chromatographic column was a C8 $(250 \times 4 \mathrm{~mm}$ and $5 \mathrm{~nm}$ average particle size) placed inside an oven with temperatures set at $25^{\circ} \mathrm{C}$. Chromatograms were made using isocratic elution $(1 \mathrm{~mL}$ $\mathrm{min}^{-1}$ ) with mobile phase containing acetonitrile/ $0.05 \%$ trifluoracetic acid $(70 / 30 \% \mathrm{v} / \mathrm{v})$. Sample was prepared in methanol and injection volume was $15 \mu \mathrm{L}$. Under such conditions, analyte retention time was $2.8 \mathrm{~min}$. Acid-base titrations were performed in a Metrohm Titration Automatic system with a combined glass electrode $(\mathrm{KCl}$ $\left.3 \mathrm{~mol} \mathrm{~L}^{-1}\right)$

\section{Solutions and reagents}

Ultrapure water was obtained from a water ultra purification Milli-Q system from Millipore (Simplicity model 185). Analytical grade (glacial acetic acid, phosphoric acid, boric acid, sodium chloride and citric acid, sodium hydroxide, potassium hydroxide, potassium nitrate, potassium acid phthalate, sodium acetate and methanol) were from Merck (Darmstadt, Germany). Sibutramine hydrochloride standard was obtained from Abbott Ireland Pharmaceutical with $99.6 \%$ purity.

Mcllvaine $\mathrm{pH} 4.0$ buffer was prepared mixing $0.2 \mathrm{~mol}$ of $\mathrm{Na}_{2} \mathrm{HPO}_{4}$ and $0.1 \mathrm{~mol}$ of citric acid with water to obtain $1 \mathrm{~L}$ volume of solution. Britton-Robinson buffer $\left(0.1 \mathrm{~mol} \mathrm{~L}^{-1}\right)$ was prepared by mixing $0.1 \mathrm{~mol}$ acetic acid, $0.1 \mathrm{~mol}$ boric acid and $0.1 \mathrm{~mol}$ phosphoric acid with water to obtain $1 \mathrm{~L}$ volume of solution. The $\mathrm{pH}$ of these buffers was adjusted by the addition of aliquots of sodium hydroxide solution $2 \mathrm{~mol} \mathrm{~L}^{-1}$.

\section{Samples}

Medicine samples from three different laboratories were used: Biomag (similar medicine containing either 10 or $15 \mathrm{mg}$ of the analyte/capsule) from Aché laboratories from which were taken two samples each one from a different lot, sample 1 (15 mg of sibutramine- $\mathrm{HCl})$ and sample $2(10 \mathrm{mg}$ of sibutramine- $\mathrm{HCl})$; Vazy (similar medicine containing $15 \mathrm{mg}$ of the analyte/capsule) from Sigma Pharma laboratories which was named sample 3; and Chloridrato de sibutramina (generic medicine containing $15 \mathrm{mg}$ of the analyte/capsule) from Sandoz, which was named sample 4. Seven independent subsamples were prepared for each one of the different lots and analyzed using both the proposed method and a HPLC method. Samples were prepared weighing an appropriate amount of sample and dissolving it in deionized water (for DPV) or in methanol (for HPLC). The sample was left in ultrasonic bath for $10 \mathrm{~min}$.

Three different brands of commercial energy drink (E1, E2 and E3) and two brands of green tea (T1 and T2) were fortified with sibutramine and analyzed by differential pulse voltammetry (DPV). Volumes $(750 \mu \mathrm{L})$ of these samples were added directly into the supporting electrolyte (Mcllvaine buffer) in the electroanalytical cell.

\section{Voltammetric measurements}

A $10 \mathrm{~mL}$ volume of the supporting electrolyte solution (Mcllvaine buffer $\mathrm{pH} \mathrm{4,} 0.1 \mathrm{~mol} \mathrm{~L}^{-1}$ ) was transferred to the working borosilicate cell and then purged with nitrogen for $1500 \mathrm{~s}$ (and for $20 \mathrm{~s}$ before each adsorptive cycle). Analyte determinations using differential pulse technique were performed by scanning the potential from +170 to -70 $\mathrm{mV}$. Volumes of samples $(750 \mu \mathrm{L})$ were placed in the electrochemical cell containing the supporting electrolyte. The solution was stirred ( $30 \mathrm{~s}$ ) and then stopped $15 \mathrm{~s}$ (equilibrium time) before recording the voltammograms (scan rate of $40 \mathrm{mV} \mathrm{s}^{-1}$ and pulse amplitude of 50 $\mathrm{mV})$. Cycles were repeated with a fresh medium size mercury drop, chosen because of the better precision of results. All reported values (signal intensities and maximum potentials) were calculated based on the average of at least three replicate measurements. Cyclic voltammograms were obtained by first using a direct scan from +200 to $-600 \mathrm{mV}$ and then reversing the direction (inverse scan) from -600 to $+200 \mathrm{mV}$.

Determinations in green tea and energy drink were made by analyte addition technique while the pharmaceutical formulations were analyzed using an external analytical curve.

\section{Acid-base titrations}

For titration studies, $10 \mathrm{~mL} \mathrm{KNO}_{3} 1.2 \mathrm{~mol} \mathrm{~L}^{-1}$ and $10 \mathrm{~mL} \mathrm{H}_{2} \mathrm{O}$ was added into a cell, kept at $25^{\circ} \mathrm{C}$, containing $100 \mathrm{~mL}$ of sibutramine $10^{-3}$ mol L ${ }^{-1}$ solution. The titration was made with a $0.100 \mathrm{~mol} \mathrm{~L}^{-1} \mathrm{KOH}$.

\section{RESULTS AND DISCUSSION}

\section{Optimization of experimental conditions}

Preliminary studies were performed in order to find a suitable supporting electrolyte for sibutramine- $\mathrm{HCl}$ using the HMDE. BrittonRobinson buffer was first studied since this buffer offered the possibility to study a wide $\mathrm{pH}$ range (2-12), allowing search the most suitable $\mathrm{pH}$ to observe the sibutramine- $\mathrm{HCl}$ voltametric signal. For $\mathrm{pH}$ values higher than 6, no signal characteristic of the analyte was observed. In the acid $\mathrm{pH}$ range, the magnitude of the signal was almost invariable in the $\mathrm{pH}$ range between 3.0 and 6.0 with analyte peak maximum varying from $-139 \mathrm{mV}(\mathrm{pH} 2)$ to $-92 \mathrm{mV}(\mathrm{pH} 6)$ remaining constant at 107 $\mathrm{mV}$ between $\mathrm{pH} 3$ and 5 (Figure 1). Analyte peak with a better shape (symmetric and with smaller width at half maximum) and a smaller background noise were obtained using the supporting electrolyte at

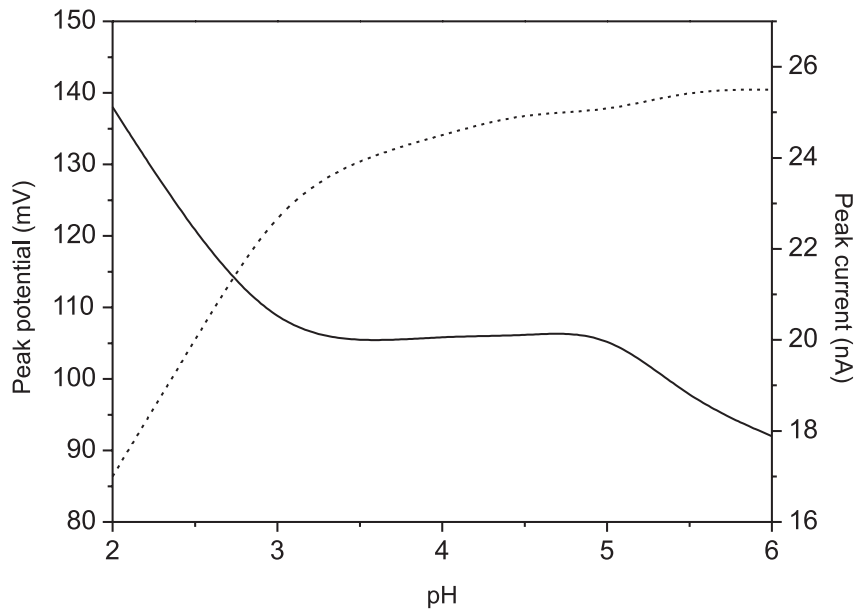

Figure 1. Peak current (Ip) and peak potential (Ep) curves of sibutramine- $\mathrm{HCl}$ in funcition of the $\mathrm{pH}$ (Britton-Robinson buffer $0.04 \mathrm{~mol} \mathrm{~L} \mathrm{~L}^{-1}$ ) 
$\mathrm{pH}$ 4.0. In addition, the shift in peak potential was constant between $\mathrm{pH} 3.0$ and $\mathrm{pH} 5.0$ which means that the choice of $\mathrm{pH} 4.0$ produced a robust condition with respect to the peak potential.

The evaluation of the analytical response of sibutramine- $\mathrm{HCl}$ in other $\mathrm{pH} 4$ buffered systems was done using Mcllvaine buffer, acetate buffer and potassium hydrogen phthalate buffer. The best results have been achieved with Mcllvaine buffer ( $\mathrm{pH}$ 4.0) since it enabled a peak at least 1.4 times more intense than the ones achieved with the others buffer as well as a flat and low baseline profile, as can be seen in Figure 2. Therefore, Mcllvaine buffer $\mathrm{pH} 4.0$ was chosen as the supporting electrolyte.

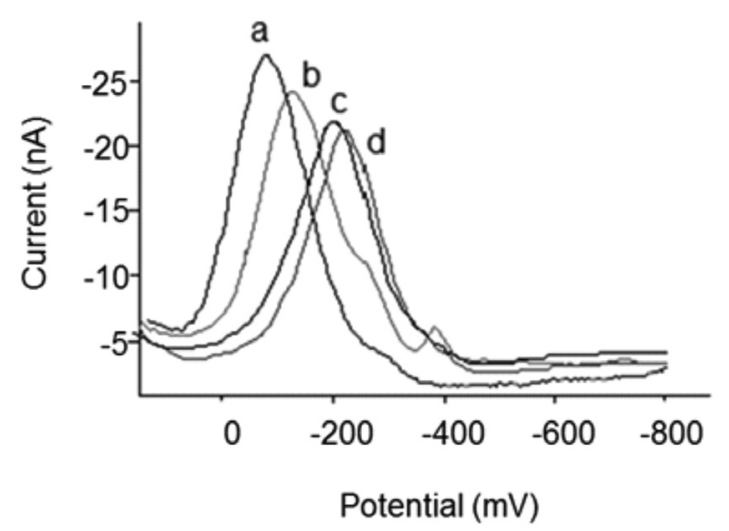

Figure 2. Voltammetric peak profiles (differential pulse) of sibutramine- $\mathrm{HCl}$ in (A) Mcllvaine buffer pH 4; (B) Mcllvaine Britton-Robinson pH 4; (C) potassium hydrogen phthalate $\mathrm{pH}$ 4; (D) acetate buffer $\mathrm{pH} 4$

In order to improve signal, different scan velocities (from 10 to $50 \mathrm{mV} \mathrm{s}^{-1}$ ) were tested, indicating results (current values and peak width) practically constant in the tested range. The chosen scan velocity was $40 \mathrm{mV} \mathrm{s}^{-1}$, since it would provide fast scan and lead to a robust parameter within the tested range. Pulse amplitude was evaluated from 10 to $100 \mathrm{mV}$. Although the magnitude of the faradaic current increased with increasing of pulse amplitude, a shift in the anodic peak potential is observed and a significant increasing in peak width at the half of the maximum current $\left(\Delta \mathrm{E}_{\mathrm{p} / 2}\right)$ is achieved. Therefore, a compromise between the peak intensity and the peak width was found using $50 \mathrm{mV}$ pulse amplitude, which enabled a peak maximum at $-80 \mathrm{mV}$.

\section{Mechanism insights based on cyclic voltammetry, square-wave voltammetry and acid-base chemistry}

Cyclic voltammetry was performed in order to study the electrochemical behavior of sibutramine-HCl. The study was made using $\mathrm{pH} 4.0 \mathrm{Mcllvaine}$ buffer and $50 \mathrm{mmol} \mathrm{L}^{-1}$ of sibutramine- $\mathrm{HCl}$ (Figure 3 ). The voltammogram presented a reversible behavior with the ratio between the peak current for the cathodic process $(-8.2 \mathrm{nA})$ and the peak current for the anodic process (7.9 nA) close to unity (1.04). In addition, it is observed that the difference between the cathodic peak potential $\left(\mathrm{E}_{\mathrm{pc}}=-132 \mathrm{mV}\right)$ and the anodic peak potential of the reverse scan $\left(\mathrm{E}_{\mathrm{pa}}=-73 \mathrm{mV}\right)$ is $59 \mathrm{mV}$. Such results are indicative of a reversible one electron transfer mechanism $\left(\mathrm{E}_{\mathrm{r}}\right)$. $^{24}$

Insights on the mechanism were also obtained using square wave voltammetry. ${ }^{25}$ For equivalent concentrations of sibutramine- $\mathrm{HCl}$, SWV produced peak current intensities about two times the one achieved using DPV as indicated by the ratio between the angular coefficient of the analytical curves obtained by SWV $\left(\mathrm{m}_{\mathrm{SWV}}=4.8\right)$ and by DPV $\left(\mathrm{m}_{\mathrm{DPV}}=2.1\right)$. This is characteristic of reversible systems with adsorption of the product on the electrode. The reversibility of

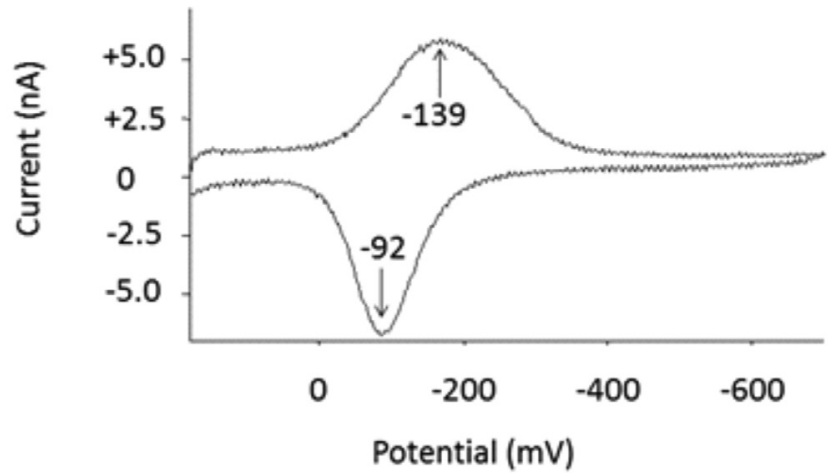

Figure 3. Cyclic voltammograms of sibutramine $0.05 \mathrm{mmol} \mathrm{L}^{-1}$ (Mcllvaine buffer $\mathrm{pH}$ 4.0)

the process was also indicated by the linear correlation $\left(\mathrm{R}^{2}=0.996\right)$ between the increase of the peak current in function of the square-root of the increased applied frequency (from 10 to $50 \mathrm{~Hz}$ ). SWV studies also showed the independence of the $\mathrm{E}_{\mathrm{p} / 2}$ value in function of both the pulse amplitude (between 10 and $40 \mathrm{mV}$ ) and the frequency (between 10 and $60 \mathrm{~Hz}$ ) which are also in agreement with the behavior of reversible systems. The lack of any linear adjustment between peak potencial and the applied frequency (in the range from 10 to $60 \mathrm{~Hz}$ ) indicates a mechanism involving the adsorption of both the reagent and the product. This adsorptive mechanism is also confirmed as the peak current linearly $\left(\mathrm{R}^{2}=0.986\right)$ increases in function of the applied pulse amplitudes up to $60 \mathrm{mV}$. The increasing in $\mathrm{E}_{\mathrm{p} / 2}$ and the constant values of peak currents for applied pulse amplitudes larger than $60 \mathrm{mV}$ is also in agreement with the adsorption of both the reagent and the product.

Sibutramine- $\mathrm{HCl}$ is the marketed form of the drug because of its higher solubility in water. In this form, the tertiary amine shares its non-bonding electron pair with an $\mathrm{H}^{+}$forming an ammonium quaternary cation (conjugate acid of sibutramine). The titration of a 1.0 $\mathrm{x} 10^{-3} \mathrm{~mol} \mathrm{~L}^{-1}$ sibutramine- $\mathrm{HCl}$ solution with a strong base indicated $\mathrm{pK}_{\mathrm{a}}$ value of $6.6\left(\mathrm{pK}_{\mathrm{b}}\right.$ value of 8.4 , which is close to the 8.5 reported in the literature). ${ }^{21}$ This result shows that an insignificant fraction (less than $0.5 \%$ ) of the drug is not protonated in aqueous solution at $\mathrm{pH}$ 4. Therefore, it is expected that the ammonium quaternary cation of sibutramine in the solution-electrode interface is adsorbed at the surface of the mercury electrode where it is easily transformed to the less soluble sibutramine at small negative potentials (Figure 4). The process is easily reversed as the inverse scan of potentials is applied. As sibutramine- $\mathrm{HCl}$ is an ammonium quaternary salt with no possible resonance structures (due to the lack of nearby groups containing $\mathrm{sp}^{2}$ orbitals, which would favor the deslocalization of electrons $)^{26}$ no further reaction can occur.<smiles>CC(C)CC(N(C)C)C1(c2ccc(Cl)cc2)CCC1</smiles>

Figure 4. Proposed redox mechanism

In order to take advantage from the adsorption of the analyte on the surface of the electrode, studies were carried out aiming to pre-concentrate sibutramine-HCl. Mcllvaine buffer ( $\mathrm{pH} 2.0$ to 5.0) as well as in Britton-Robinson buffer ( $\mathrm{pH} 2.0$ to 6.0) were used. Hydrochloric acid $0.1 \mathrm{~mol} \mathrm{~L}^{-1}$ and sulfuric acid $0.1 \mathrm{~mol} \mathrm{~L}^{-1}$ were also used as supporting electrolytes in these attempts, however, no 
success was achieved by applying potentials between 300 and $0 \mathrm{mV}$ from 20 to $100 \mathrm{~s}$.

\section{Analytical figures of merit}

Sibutramine- $\mathrm{HCl}$ analytical curve was constructed using DPV with the HMDE as the working electrode, Mcllvaine $\mathrm{pH} 4.0$ buffer, $50 \mathrm{mV}$ amplitude and $40 \mathrm{mV} \mathrm{s}^{-1}$ scan velocity. The linear range of analytical response was from $1.4 \mathrm{mg} \mathrm{L}^{-1}\left(5 \mathrm{mmol} \mathrm{L}^{-1}\right)$ to $33.3 \mathrm{mg}$ $\mathrm{L}^{-1}\left(118 \mathrm{mmol} \mathrm{L}^{-1}\right)$ with homocedastic behavior indicated by the random dispersion of results in the residual plots. In the chosen analytical working range (7.3 and $33.3 \mathrm{mg} \mathrm{L}^{-1}$ ), the determination coefficient $\left(\mathrm{R}^{2}\right)$ was 0.9994 with analytical curve equation of $\mathrm{Y}(\mathrm{nA})$ $=(2.1 \pm 0.1) X\left(\mathrm{mg} \mathrm{L}^{-1}\right)-(2.3 \pm 5.6)$. Linearity was confirmed by statistical Student-t test. In Figure 5, a sequence of voltammograms of sibutramine- $\mathrm{HCl}$ at the chosen working concentration range is shown. Limit of detection (LOD) of $0.4 \mathrm{mg} \mathrm{L}^{-1}\left(1.3 \mathrm{mmol} \mathrm{L}^{-1}\right)$ was calculated as the concentration of analyte that enabled a signal three times the standard deviation of the blank $\left(3 \mathrm{~s}_{\mathrm{b}}\right)$. The $3 \mathrm{~s}_{\mathrm{b}}$ value was obtained from the standard deviation of ten measurements on a low sibutramine concentration point of the analytical curve $\left(2.0 \mathrm{mg} \mathrm{L}^{-1}\right)$. The analyte peak corresponding to the LOD was actually identified by the instrument software. The limit of quantification (LOQ), calculated using $10 \mathrm{~s}_{\mathrm{b}}$, was $1.4 \mathrm{mg} \mathrm{L}^{-1}\left(5 \mathrm{mmol} \mathrm{L}^{-1}\right)$.

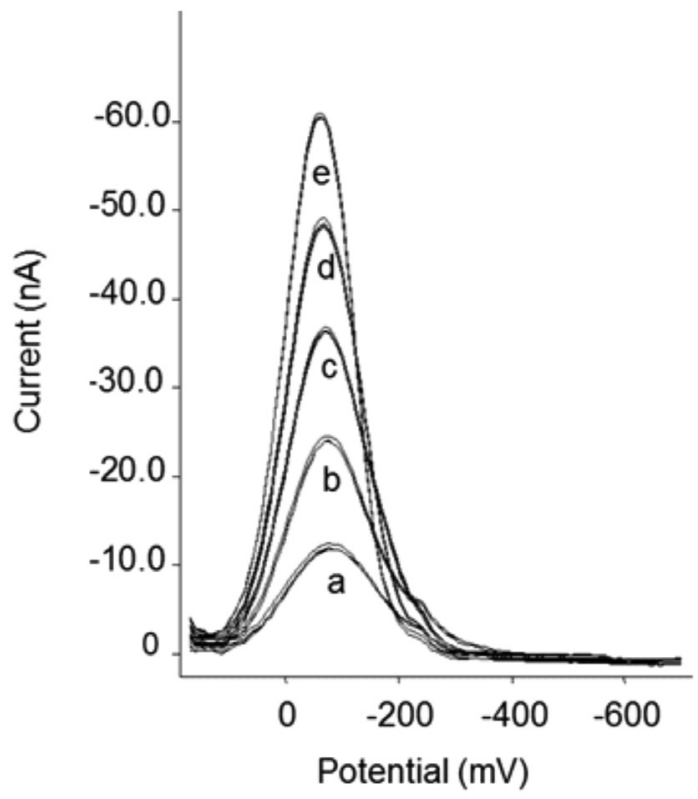

Figure 5. Volltammograms (DPV) of increasing concentrations of sibutramine (Mcllvaine pH 4.0 buffer, $50 \mathrm{mV}$ amplitude and $40 \mathrm{mV} \mathrm{s}^{-1}$ scan velocity). Sibutramine concentrations: a) $7.3 \mathrm{~mol} \mathrm{~L}^{-1}\left(23.4 \mathrm{mmol} \mathrm{L}^{-1}\right)$; b) $14.3 \mathrm{~mol} \mathrm{~L}$ (45.8 mmol L $\left.L^{-1}\right)$; c) $20.9 \mathrm{~mol} \mathrm{~L}^{-1}\left(66.9 \mathrm{mmol} \mathrm{L} L^{-1}\right)$; d) $27.3 \mathrm{~mol} \mathrm{~L} L^{-1}$ (74.9 $\mathrm{mmol}$ $\left.L^{-1}\right)$; e) $33.3 \mathrm{~mol} \mathrm{~L}^{-1}\left(106.6 \mathrm{mmol} \mathrm{L}^{-1}\right)$

Tests using the analytical curve, enabled recovery values of 95 , 98 and $104 \%(n=3)$ respectively for standard solutions of sibutramine hydrochloride (controlled samples) at three different levels (8, 20 and $\left.33 \mathrm{mg} \mathrm{L}^{-1}\right)$.

\section{Pharmaceutical sample analysis by DPV and HPLC}

In order to evaluate the potential interference from the matrix of the sibutramine- $\mathrm{HCl}$ pharmaceutical formulations, several substances were studied by adding a larger amount of each of them in the analytical cell were the signal from one standard solution of sibutramine- $\mathrm{HCl}$ was measured. This signal was compared to the value of the standard solution of sibutramine- $\mathrm{HCl}$ measured from a cell in the absence of the potential interferent. Several substances were tested at concentration levels 10 and 50 times higher than that of sibutramine-HCl. Sucrose, sorbitol and sodium glutamate did not impose any interferences at the two concentration levels using the established experimental conditions set for the determination of sibutramine- $\mathrm{HCl}$. Histidin and lactose caused no intererence when present in concentrations 10 times higher than the one of the analyte. However, at concentrations 50 times higher, a decreasing of the analyte signal (about 20\%) was imposed by phenylalanine when compared to the sibutramine- $\mathrm{HCl}$ signal measured in absence of these concomitant substances. However such type of interference can be easily corrected by using the standard additions method when quantifying the analyte. When measurements were made in the presence of phenylalanine, the sibutramine- $\mathrm{HCl}$ voltammetric signal was completely eliminated even when phenylalanine is present at the lower concentration level tested.

Pharmaceutical formulation solutions of sibutramine- $\mathrm{HCl}$ were prepared using a pool of capsules and the analyte content was determined using the proposed method and using a HPLC based method. The results in Table 1 indicated relative standard deviations no higher than $6 \%(n=7)$ for the DPV method. When the analysis results are compared with the nominal values of sibutramine- $\mathrm{HCl}$ in the pharmaceutical formulations, the recoveries varied from 92 to $100 \%$, which are within the acceptable recovery range (from 90 to $110 \%$ ) indicated in the United States Pharmacopoeia. In addition, the t-test (two-sided) was performed to compare the analytical results achieved with the proposed method with the ones achieved using HPLC. No statistical differences (at a 95\% confidence level) were found indicating the adequate performance of the DPV method.

Table 1. Sibutramine recovery results from the analysis of pharmaceutical formulations using DPV and HPLC

\begin{tabular}{cccc}
\hline Sample & $\begin{array}{c}\text { Recoveries using DPV } \\
\text { mass per tablet }{ }^{\mathrm{a}, \mathrm{b}} \\
\text { (percent recovery) }\end{array}$ & $\begin{array}{c}\text { Recoveries using HPLC } \\
\text { mass per tablet } \mathrm{t}^{\mathrm{a}, \mathrm{b}} \\
\text { (percent recovery) }\end{array}$ & $\mathrm{t}_{\text {calculated }} \mathrm{c}^{\mathrm{c}}$ \\
\hline 1 & $\begin{array}{c}14.1 \pm 0.4 \mathrm{mg} \\
(94 \%)\end{array}$ & $\begin{array}{c}13.6 \pm 0.5 \mathrm{mg} \\
(90,7 \%)\end{array}$ & 2.00 \\
2 & $\begin{array}{c}9.9 \pm 0.4 \mathrm{mg} \\
(99 \%)\end{array}$ & $\begin{array}{c}10.0 \pm 0.5 \mathrm{mg} \\
(100 \%)\end{array}$ & 0.40 \\
3 & $14.2 \pm 0.3 \mathrm{mg}$ & $14.0 \pm 0.3 \mathrm{mg}$ & 1.24 \\
& $(94.7 \%)$ & $(93.3 \%)$ & \\
4 & $13.6 \pm 0.5 \mathrm{mg}$ & $14.3 \pm 0.6 \mathrm{mg}$ & 2.37 \\
& $(90.7 \%)$ & $(95.3 \%)$ & \\
\hline
\end{tabular}

a'Based on the reported value of each pharmaceutical formulation: $10 \mathrm{mg} /$ tablet (samples 1 and 4) and $15 \mathrm{mg} /$ tablet (samples 2,3 and 5). ${ }^{\mathrm{b} C o n f i d e n c e}$ interval based on $95 \%$ confidence level and $n=7$. ${ }^{\circ}$ Two-sided Student $t$-test at $95 \%$ confidence level comparing the result obtained with DPV with the one achieved with HPLC.

\section{Analysis of beverages}

The DPV proposed method was also used to quantify sibutramine$\mathrm{HCl}$ in beverages. Energy drinks and commercial green tea (as a ready to drink liquid beverage) were fortified with sibutramine- $\mathrm{HCl}$ (200 $\mathrm{m} \mathrm{L} \mathrm{L}^{-1}$ ) and analyzed. In order to evaluate the interference from the sample matrices, the standard addition curve made in a cell containing a volume of the sample (energy drink or tea) was compared to a standard addition curve made in a cell only containing the supporting electrolyte. The sensitivities of the curves obtained in the presence of the energy drink $\left(\mathrm{m}=1.6 \mathrm{nA} \mathrm{L} \mathrm{mg}^{-1}\right)$ and of the tea $(\mathrm{m}=1.4 \mathrm{nA} \mathrm{L}$ $\mathrm{mg}^{-1}$ ) was smaller than the one achieved in the cell without samples $\left(\mathrm{m}=2.1 \times 10^{-6} \mathrm{nA} \mathrm{L} \mathrm{g}^{-1}\right)$. The result indicated that the complexity of 
the sample matrices imposed a certain degree of interference in the voltammetric measurements, which, in turn, because of the type of the interference that decreases the analyte signal, it could be circumvented by the use of the standard addition method for the analysis.

In order to verify the accuracy of the method, all samples were also analyzed using the HPLC based method. Recoveries obtained from the energy drink samples (E1, E2 and E3) were between 96 and $101.3 \%$ and for green tea samples (T1 and T2) the recovery results were between 98 to $102.2 \%$ as indicated in Table 2. Statistical t-test indicated that the results achieved by DPV are equivalent to the ones achieved by HPLC.

Table 2. Recovery results for sibutramine fortified energy drinks (E) and green tea $(\mathrm{T})$ samples $^{\mathrm{a}}$

\begin{tabular}{|c|c|c|c|}
\hline Sample & $\begin{array}{l}\text { Recoveries using DPV } \\
\text { concentration }{ }^{\mathrm{b}, \mathrm{c}} \\
\text { (percent recovery) }\end{array}$ & $\begin{array}{l}\text { Recoveries using HPLC } \\
\text { concentration }^{\mathrm{b}, \mathrm{c}} \\
\text { (percent recovery) }\end{array}$ & $\mathrm{t}_{\text {calculated }}{ }^{\mathrm{d}}$ \\
\hline E1 & $\begin{array}{c}192.3 \pm 6.1 \mathrm{mg} \mathrm{L}^{-1} \\
(96.1 \%)\end{array}$ & $\begin{array}{c}199.4 \pm 12.3 \mathrm{mg} \mathrm{L}^{-1} \\
(99.7 \%)\end{array}$ & 0.90 \\
\hline E2 & $\begin{array}{c}195.1 \pm 6.0 \mathrm{mg} \mathrm{L}^{-1} \\
(97.5 \%)\end{array}$ & $\begin{array}{c}197.4 \pm 6.5 \mathrm{mg} \mathrm{L}^{-1} \\
(98.7 \%)\end{array}$ & 0.45 \\
\hline E3 & $\begin{array}{c}198.7 \pm 4.2 \mathrm{mg} \mathrm{L}^{-1} \\
(99.3 \%)\end{array}$ & $\begin{array}{c}202.5 \pm 15.3 \mathrm{mg} \mathrm{L}^{-1} \\
(101.2 \%)\end{array}$ & 0,41 \\
\hline $\mathrm{T} 1$ & $\begin{array}{c}195.9 \pm 8.4 \mathrm{mg} \mathrm{L}^{-1} \\
(98 \%)\end{array}$ & $\begin{array}{l}202.5 \pm 5.4 \mathrm{mg} \mathrm{L}^{-1} \\
\quad(101.2 \%)\end{array}$ & 1.14 \\
\hline $\mathrm{T} 2$ & $\begin{array}{c}204.3 \pm 11.0 \mathrm{mg} \mathrm{L}^{-1} \\
(102.1 \%)\end{array}$ & $\begin{array}{c}200.1 \pm 9.5 \mathrm{mg} \mathrm{L}^{-1} \\
(100 \%)\end{array}$ & 0.50 \\
\hline
\end{tabular}

${ }^{\mathrm{a}}$ Number of standard additions $(\mathrm{n}=3)$; ${ }^{\mathrm{b}}$ based on the fortified value: 200,0 $\mathrm{mg} \mathrm{L}^{-1}$ for the Energetic drinks (E1, E2 and E3) and 9,0 $\mathrm{mg} \mathrm{L}^{-1}$ for the tea samples (T1 and T2); ${ }^{\mathrm{c}}$ confidence interval based on $95 \%$ confidence level and $\mathrm{n}=3$; ${ }^{\mathrm{d}}$ two-sided Student $\mathrm{t}$-test at $95 \%$ confidence level comparing the result obtained with DPV with the one achieved with HPLC.

\section{CONCLUSION}

The proposed differential pulse voltammetric method was adequate for the determination of sibutramine as indicated by the results achieved in the analysis of pharmaceutical formulations and beverages. Interferences observed in the analysis of beverages could be eliminated by using the standard addition method, quantification procedure that is suitable and usual in voltammetric determinations. The proposed method presented some advantages over the traditional methods based on liquid chromatography, enabling fast analysis that do not requires sample preparation and the use of expensive supplies such columns, filters and HPLC-grade solvents. In addition, DPV employs less expensive equipment that in some cases allows the automatization of the method for routine analysis.

\section{ACKNOWLEDGEMENTS}

The following scholarships are acknowledged: CNPq (R. Q. Aucélio and J. M. Carvalho), FAPERJ (R. Q. Aucélio) and CAPESPNPD project (A. R. da Silva). The authors thank scientific funding from FINEP-MCT, CNPq and FAPERJ.

\section{REFERENCES}

1. http://www.who.int/nutrition/topics/obesity/en/index.html, accessed January 2012.

2. Warren, E.; Brennan, A.; Akehurst, R.; Med. Decis. Making 2004, 24, 9.

3. Bello, N. T.; Liang, Nu-Chu.; Drug Design, Development and Therapy 2011, 5, 95.

4. Snow, V.; Barry, P.; Fitterman, N.; Qaseem, A.; Weiss, K.; Ann. Internal Med. 2005, 142, 525.

5. Heal, D. J.; Cheetham, S. C.; Prow, M. R.; Martin, K. F.; Buckett, W. R.; Br. J. Pharmacol. 1998, 125, 301.

6. Zu, H.; Wu, H.; Chen, J.; Men, C.; Jang, Y.-S.; Kang, W.; Choi, J. K.; Lee, W.; Kang, J. S.; Bull. Korean Chem. Soc. 2010, 31, 6.

7. Amundsen, M. O.; Engdahl, B.; Berg, C.; Nordeng, H.; Pharm. World Sci. 2010 32, 752.

8. Rucker, D.; Padwal, R.; Li, S. K.; Lau, D. C.; Br. Med. J. 2007, 335, 1194.

9. http://www.usp.org/pdf/EN/referenceStandards/msds/1612845, accessed January 2012.

10. http://www.ema.europa.eu/ema/index.jsp?curl=pages/medicines/human/ referrals/Sibutramine/human_referral_000219.jsp\&murl=menus/ regulations/regulations.jsp\&mid=WC0b01 ac0580024e9a, accessed January 2012.

11. http://www.fda.gov/Drugs/DrugSafety/ucm228746.htm., accessed January 2012.

12. http://portal.anvisa.gov.br/wps/portal/anvisa/imprensa/!ut/p/c4/04_SB 8K8xLLM9MSSzPy8xBz9CP0os3hnd0cPE3MfAwMDMydnA093 Uz8z00B_A3dLE_2CbEdFAJSoWeQ!/?WCM_PORTLET=PC_7_ CGAH47L0006BC0IG5N65QO0OM4_WCM\&WCM_GLOBAL_ CONTEXT=/wps/wcm/connect/anvisa/anvisa/sala+de+imprensa/ noticias/anvisa+esclarece+nova+resolucao+sobre+sibutramina, accessed January 2012.

13. http://www.fda.gov/Drugs/DrugSafety/ucm228746.htm, accessed January 2012.

14. http://www.anvisa.gov.br/divulga/noticias/2007/150607_2.htm, accessed January 2012.

15. Diefenbach, I. C. F.; Friedrich, M.; Santos, M. R.; Bittencourt, C. F.; J. AOAC Int. 2009, 92, 148.

16. Satoshi, I.; Shiori, M.; Mitsunorio, O.; Osamu, E.; Gen, S.; J. Health Sci. 2009, 55, 183.

17. Chen, Y.; Zhao, L.; Lu, F.; Yu, Y.; Wu, C. Y.; Food Addit. Contam., Part A 2009, 26, 595 .

18. Carvalho, L. M.; Martini, M.; Moreira, A. P.; Garcia, S. C.; Nascimento, P. C.; Bohrer, D.; Microchem. J. 2010, 96, 114.

19. Obreshkova, D.; Peykova, L.; Bulgarian Academy of Sci. 2010, 63, 1137.

20. Lu, F.; Li, S.; Le, J.; Chen, G.; Cao, Y.; Qi, Y.; Chai, Y.; Wu, Y.; Anal. Chim. Acta 2007, 589, 200.

21. Carvalho, L. M.; Martini, M.; Moreira, A. P. L.; Lima, A. P. S.; Correia, D.; Falcão T.; Garcia, S. C.; Bairros, A. V.; Nascimento, P. C.; Bohrer, D.; Forensic Sci. Int. 2011, 204, 6.

22. Carvalho, L. M.; Nascimento, P. C.; Bohrer, D.; Correia, D.; Bairros, A. V.; Pomblum, V. J.; J. Braz. Chem. Soc. 2007, 18, 789.

23. Noh, K.; Bae, K.; Min, B.; Kim, E.; Kwon, K.; Jeong, T.; Kang, W.; Arch Pharm Res. 2010, 33, 267.

24. Grosser, D. K.; Cylic voltammetry: simulation and analysis of reaction mechanisms, 1st ed., Wiley-VCH: New York, 1993.

25. de Souza, D.; Machado, S. S. A.; Avaca, L. A.; Quim. Nova 2003, 26, 8.

26. Cases, F.; Huerta, F.; Garcés, P.; Morallón, E.; Vázquez, J. L.; J. Eletctroanal. Chem. 2001, 501, 186. 